\title{
35. THE PALEOECOLOGY OF THE OSTRACODES OF DSDP LEG 42A
}

\author{
Richard H. Benson, Smithsonian Institution, Washington, D.C.
}

Twenty-three ostracode species, identified from 652 specimens, were found in 61 samples from seven of the eight sites of Leg 42A. Most of the samples were core fractions $5 \mathrm{~cm}$ long $(50 \mathrm{cc})$. Eleven additional samples contained no ostracodes; these samples were generally concentrated in suspected azoic horizons. The highest rate of specimen recovery was in the Cyprideis Zone (Pannonian-Messinian), especially in the eastern Mediterranean (Site 376), where restricted marine conditions also produced the fewest ostracodes both before and after the late Miocene "salinity crisis."

Site 372, on the west flank of the Algero-Provencal Basin, represents the most complete cored section in the western Mediterranean. It also yielded the most complete record of change in the marine ostracode faunas (24 samples from Burdigalian through Piacenzian). Only the Pleistocene and the lowermost Pliocene samples from this site $(1-3,51-57 \mathrm{~cm}$ and 4-2, 50-56 $\mathrm{cm}$ ) contain no ostracodes. The post-"salinity crisis" fauna was best represented in the western Mediterranean at Site 371 and in the eastern Mediterranean at Site 376.

Compared with the results of the ostracode study of Leg 13 (Benson, 1973b), which had one-fourth as many samples, yielding one-sixth as many specimens from nine species, the results of this report are considered reliable. Their value is best expressed in terms of the broader changes they reflect in bottom-water mass conditions that took place in the Mediterranean basins before and after the Messinian. Unfortunately, because the samples required were too large or the faunas poor, their poorest resolution is in representing the rapid events that occurred immediately before and after the salinity crisis; in these cases faunas from outcrops, such as Falconara in Sicily, can be examined for comparison.

The results of this study can be expressed in two parts: those confirming the marine changes that affected the western and the eastern deep basins, which can be demonstrated to have existed throughout the record represented; and the Paratethyan influences during "salinity crisis," which produced the most abundant fossil record.

In my opinion, the most important discovery of this study was the occurrence of a typical deep-sea Atlantic and World Ocean ostracode species (Bradleya dictyon) in the middle Miocene of Site 372. This is not the first time psychrospheric ostracodes have been found in the middle Miocene of the central or western Mediterranean (Benson, 1973a; Serravallian of Sicily). It con- firms the existence of deep basins (estimated depth $1500 \mathrm{~m}$ or more) before the crisis, deeper oceanic influences than known before, and indicates further that the limiting threshold (Iberian Portal) was effective enough to sustain this fauna for more than 10 million years.

For those who propound the deep-basin desiccation model (Ryan, Hsü, et al., 1972; Cita, 1973), the presence of Cyprideis faunas (in situ and well represented), in nine Messinian samples from Site 376 on the Florence Rise just west of Cyprus, provides further evidence of continental influence over marine influence (the existence of lac mer or caspibrackish conditions). Yet this evidence does not resolve the problem of the water depth in the basins. Some basins could have been deep and some shallow. Where it is known in the live state, Cyprideis is a moderately shallow water euryhaline ostracode. Whether it could have existed in well-ventilated brackish waters several hundred meters deep is simply not known. What is known is that when Cyprideis lives in shallow waters of moderate salinity ranges (near normal marine), it is almost always found with other well-known euryhaline marine ostracodes; this is not so in the Messinian faunas of the cores described in this report. That its salinity range also includes normal marine conditions is very weak evidence for the entrance of seawater into the Mediterranean during the Messinian.

If the faunas of the clays between the evaporites represent the source of waters (brines?) containing the salts, they probably came from the vast continental lakes of Paratethys. No indigenous Atlantic, Red Sea, or Indian Ocean shallow-water, marine euryhaline ostracodes have yet been found or recognized in Mediterranean Messinian (post-marine) deposits. If the brines came from these sources, they were sterilized of these species (along the bottom, since these are benthic species) on their way into the basins. The presence of Paratethyan ostracodes may not indicate that Paratethys flowed into the Mediterranean basins. It is possible that Cyprideis can be flown in by birds (suggesting that at least the first invaders came in as shallow-water animals). However, it is easier to explain a massive faunal invasion by a direct connection, and perhaps this can be found.

Marine ostracodes may be used as depth indicators, but water depth is not the only ecological variable affecting their distribution. Rapid temperature change is the most formidable gradient, after that of salinity change, for species to cross. Depth is of less ecologic 
importance in a thermospheric deep sea than in an ocean with its polar-derived water masses and a more or less permanent thermocline. During times of restriction in a basin that is a satellite to the World Ocean, the shallow faunas extend their normal depth ranges downward, whereas in glacial times of psychrospheric build-up (raising of the CCD), the ranges of the oceanic fauna are telescoped upward. It is questionable that the present Mediterranean or the Atlantic represents an adequate scale for comparison. When in the middle or late Miocene did the water-mass structure of deep southern Tethys (the geographic name poses a problem) become equivalent to those of the present thermospheric western or eastern Mediterranean? It was not during the Serravallian or the Pliocene. During both of these times deep animals were present that are now extinct in the Mediterranean. The answer to depth relationships will eventually have to be given through an understanding of the history of water-mass structural history.

\section{THE VALUE AND LIMITATIONS OF THE OSTRACODES}

In other reports (Benson, 1975a,b), I have presented some of the arguments why the ostracodes, as rare but complex animals, are good indicators of past oceanographic events. They become more architecturally sophisticated under environmental stress, and their many species reflect rather restricted evolutionary paths through whatever environmental paths they might have survived. Their rarity has the disadvantage that they can be overlooked in small samples. On the other hand, their presence, at least in large numbers, is itself rarely accidental.

Among the species found in cores of Leg 42A, two are of special importance. Bradleya dictyon is a common deep-sea species (Benson, 1972), known in the Atlantic and southern parts of the World Ocean from lower Miocene to Recent. It was found outside of the deep sea in outcrop or away from the ocean floor for the second time in the pre-Messinian cores of Site 372A. The first recording of such an anomalous presence was in strata of the same age in the Betic ("El Cuervo" Section north of Cadiz; Benson, in press) of Andalusia, Spain. Oceanic continuity between these occurrences and an extensive record in the DSDP cores of the Atlantic (Benson, 1972, 1975a,b, in press) can be reasonably inferred. Its present living distribution, at depths always below 1000 meters (with Hyphalocythere at as much as $3000 \mathrm{~m}$ ), indicates by analogy the intrusion of the psychrosphere into deep Miocene basins now occupied by the Mediterranean. This species, or its psychrospheric ally Agrenocythere hazelae (Plate 1, Figure 7), has not yet been found in strata of the same age in the eastern Mediterranean. However, the latter species is well known from upper Eocene deep trough facies from alpine basin deposits in northern Italy and Yugoslavia.

The second ostracode species of considerable importance is Cyprideis pannonica (Plate 2, Figures 4-8), that Paratethyan species so common to interevaporitic facies within the Messinian. Cyprideis is a well-known ostracode (Decima, 1964), described from many parts of the world. It is a euryhaline inhabitant of marginal and continental environments, where the salinity may rise through a range much greater than that in the marine environment, but whose salts may as likely be alkaline as saline. It occurs rarely in the sea, but never as more than an accessory member of a fauna. It is present in great numbers and in all growth stages as well-preserved in situ fossil remains (all latter growth stages present, shells not worn) in Cores 7 through 13 at Site 376. It is a common "Caspibrackish" species in Paratethyan deposits ranging in age from early Miocene to the present day in the Black and Caspian seas (see discussions in Benson, in press; Krstić, 1968; Sokač, 1972; Caspers, 1957). Citations of the random occurrence of Cyprideis littoralis in marginal marine deposits, as in bays near Arcachon or in the Netherlands, do not detract from the typical development of Cyprideis pannonica (almost always with a thick shell and no nodes) as the sole or dominant member of highly saline (or alkaline) shallow waters away from the strong influence of the oceans (environmentally if not geographically). Cyprideis or an ancestor has lived in these marginal or continental situations since Mesozoic times, as a primary contributor to the residual biomass.

With confidence about the overall paleo-environmental significance of Cyprideis there is equal doubt about its environmental range and genetic limitations. How deep can it live? What does the absence of nodes among the instars indicate about the salinity (alkalinity) range? Are the slightly different morphologic variants actually genetically, and therefore historically, separate species, or just ecomorphotypes? They are not found in the euxinic levels of the Black Sea, or at great depths in the Caspian Sea (greater than $50 \mathrm{~m}$ ). They are found in the brackish $(10-15 \%$ ) Baltic (Elofson, 1941), but so are many other ostracodes. Also, the Baltic is shallow. There are no true Recent analogues for a large Paratethyan model beyond these. Both Krstic (1971) and Pokorny (1952) consider that the salinity of Paratethys was no greater than $8 \%$. In the Great Lakes of North America, the normally shallow fresh-water ostracodes live at depths of 50 meters (Benson and MacDonald, 1963). Is it not possible for Cyprideis to live in waters several hundred meters deep? One can conclude by analogy that Cyprideis may have always lived in shallow waters, but suitable analogues are in exceedingly short supply.

Deep-water marine ostracodes are seldom as sensitive to short-term environmental changes as shallow water ostracodes. Significant evolutionary changes take place, however, in two deep genera between the middle Miocene and the Pliocene: Agrenocythere hazelae, which first occurs in the Paleogene, becomes A. pliocenica; and Oblitacythereis ruggierii, which is typical of the middle Miocene, becomes $O$. mediterranea (Plate 1, Figures 5,6). Both ostracodes are large in the oldest portion of the cores of Site 372, become smaller into the Tortonian $(O$. ruggierii known from Serravallian and Tortonian continental outcrops), and then reappear as large, well-developed forms in the Pliocene. 
This change probably indicates warming trends, beginning long before the salinity crisis, and later the influx of cold waters after the crisis.

Lastly, several ostracode genera, such as Krithe, Cytherella (Plate 2, Figure 3), and Henryhowella (Plate 1 , Figure 3 ), are known to have broad depth ranges in the Mediterranean today, and perhaps also during the geologic past. In the open ocean, Krithe is one of the most common "deep-sea" ostracodes, and occurs often in abyssal assemblages. Species of this genus can be ecomorphically divided into two types, according to whether the marginal vestibule is open (poorly oxygenated waters; less than $5 \%$ ), after a scheme proposed by Peypouquet (1975) for the fauna of the Golfe de Gascogne. Leg 42A specimens of Krithe indicate poorly ventilated bottom waters wherever they were found in the eastern Mediterranean (Plio-Pleistocene), and good circulation or oxygenation in middle Miocene cores of Site 372 older than mid-Tortonian. Restricted circulation is indicated in upper Pliocene and Pleistocene cores of Site 371 and, upon rechecking, in cores of Site 132, Leg 13.

In the Atlantic, Henryhowella is also common to great and not so great depths. An adequate ecomorphic depth sequence has not been worked out for this genus. Cytherella is not so common now, but during the warmer stages of oceanic development (prior to 40
m.y.B.P.), it was also common to the deep sea. Its size and its tendency to develop marginal rims and papillae are typical of deep- or cold-water species.

Neither these ostracodes nor any found on Leg 42A have the eyes or eye tubercles common to assemblages in waters shallower than $600-800$ meters.

\section{COMPARISONS AMONG THE OSTRACODE FAUNAS}

Figure 1 shows the changes among the ostracode faunas through time and differences between those found in the western and eastern basins. The faunas were all deep-water ostracode faunas, with the possible exception of the Messinian caspibrackish fauna, which is thought to be shallow, but whose potential lower depth limits are not known. The psychrospheric fauna is deep (oceanic, probably greater than $1500 \mathrm{~m}$ ) in the middle Miocene, and contains Bradleya and "Hyphalocythere?" (Plate 1, Figure 4; Plate 2, Figure 1) in the western basin (Site 372; faunas listed in Tables 1, 2, and 3 , and their relative abundances summarized in Figures 4 and 5). It is not as deep in the lower Pliocene, which contains Agrenocythere pliocenica (known with other psychrospheric genera such as Quasibuntonia and Bythoceratina from Zanclian "Trubi" Formation outcrops in Sicily; Benson, 1972).

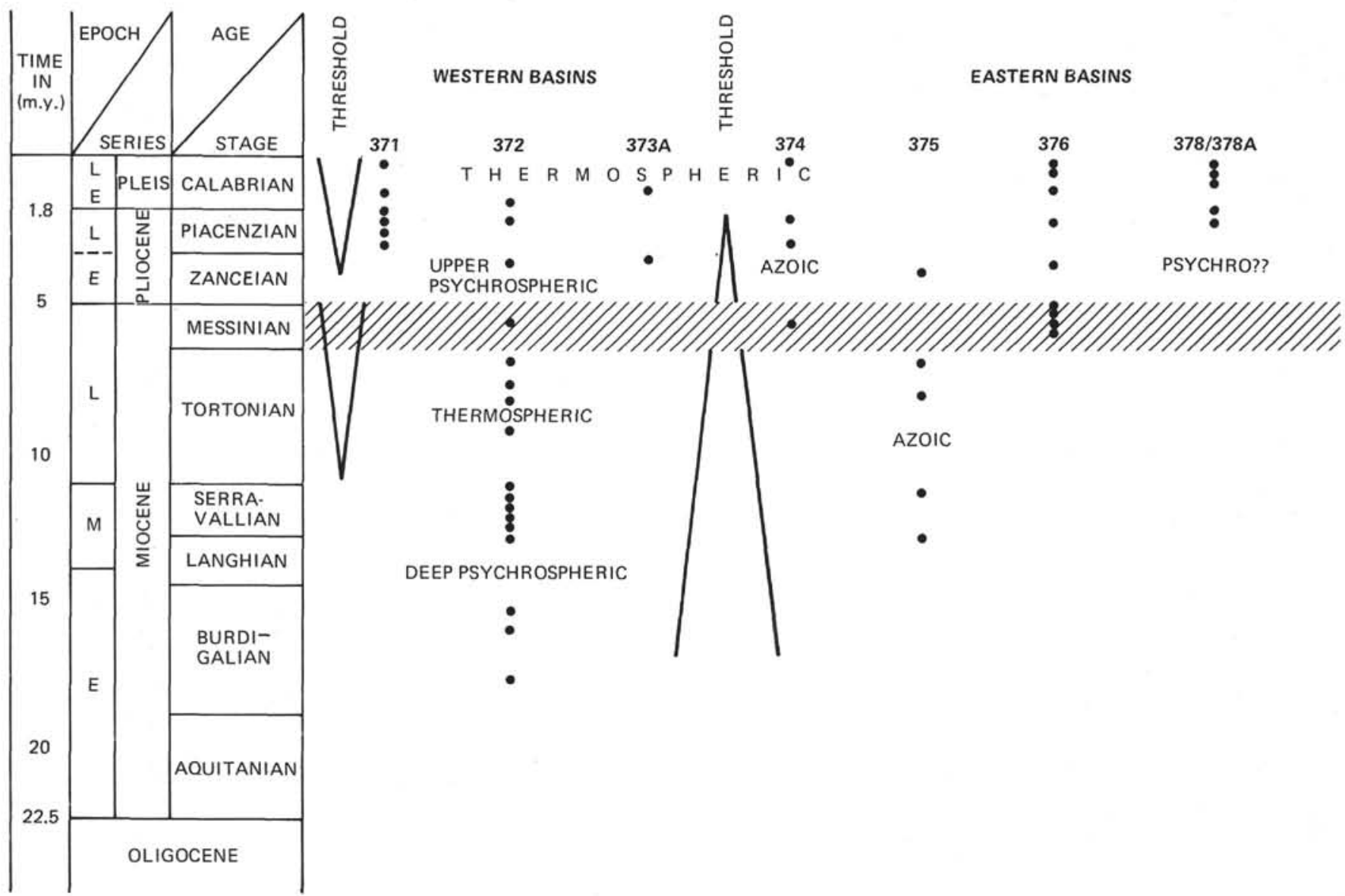

Figure 1. The distribution of ostracode samples (dots) in cores of Leg $42 \mathrm{~A}$ sites showing the changes in bottom fauna and inferred water mass conditions and the extent of threshold control. 
TABLE 1

Site 371, South Balearic Basin

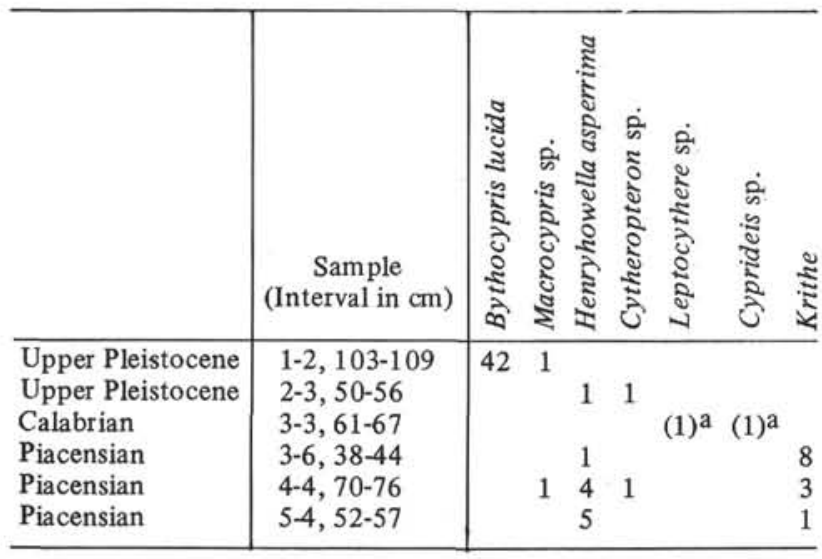

aAllochthonous.

TABLE 2

Site 372 - Algero-Provençal Basin

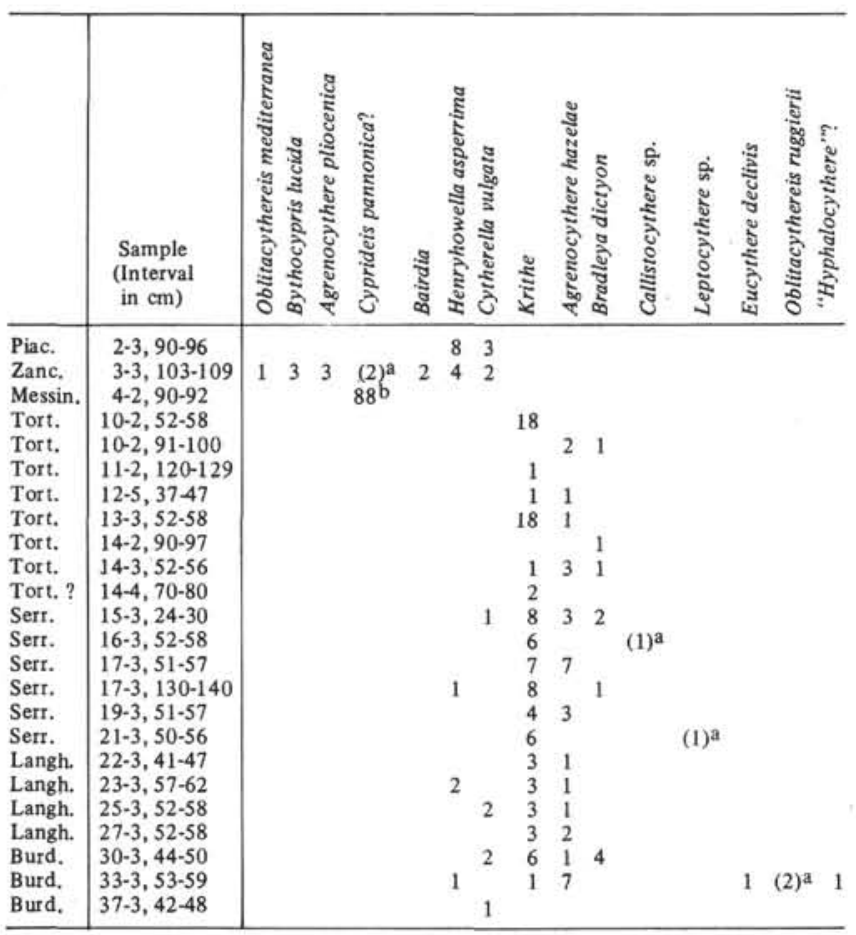

aAllochthonous,

bNumber extrapolated to equivalent size sample.

This upper psychrospheric fauna represents the influences of an upper level oceanic water mass crossing a threshold with a limiting capacity of waters no deeper than 1000 to 1500 meters. Of course, the actual depths of the Mediterranean basins are not known, but some were at least this deep, according to the ostracodes.

In both the earliest late Miocene and at the end of the Pliocene the psychrospheric faunas disappeared and were replaced in the basins by a special, submergent high bathyal fauna tolerant of increased temperatures. These thermospheric faunas are not shelf faunas in any sense. In their earliest development they are characterized by Oblitacythereis, which was an inhabi-
TABLE 3

Sites $\mathbf{3 7 5}$ and $\mathbf{3 7 6}$ - Florence Rise

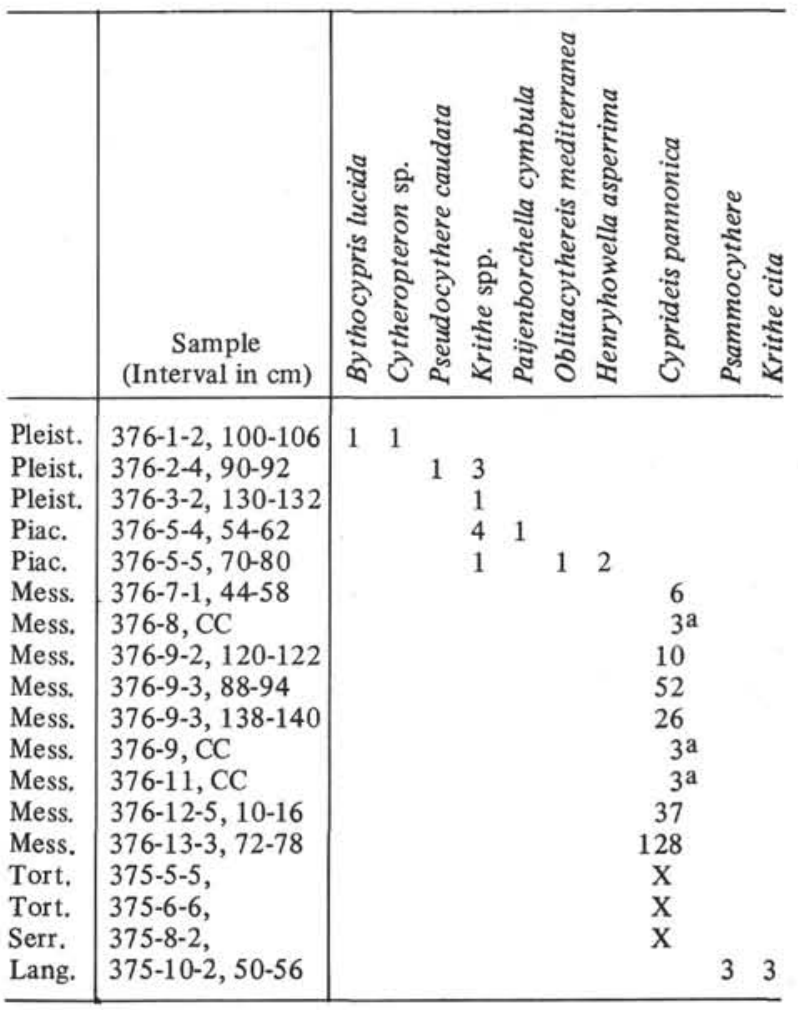

aNumber extrapolated to equivalent size sample

tant of the transitional facies between psychrospheric and shelf forms. This was a short-lived interval in faunal development, however. As the basins filled with waters with temperatures above $12^{\circ} \mathrm{C}$, as are the present basins, only the most tolerant or eurybathic species persisted. The Pleistocene basin faunas are of this kind, although the time of their development is uncertain, mainly because the Pliocene psychrospheric and Pleistocene thermospheric species may have been mixed in the Calabrian stratotype region.

The Messinian caspibrackish fauna, as discussed in the previous section, is monospecific (Cyprideis pannonica), and found throughout the Mediterranean region in clays between evaporite zones, and even within a few centimeters of the invading Pliocene psychrospheric fauna. It is the most abundant of all of the faunas found in the cores of Leg 42A. Most of the growth stages of the autogenetic series of the single species are well represented. The specimens are well preserved. There is little or no contamination from the presence of other species. There is no indication of allochthony. This fauna represents a radical change in conditions, as shown in Figure 2, from a progressive warming trend in the marine faunas to a sudden continentalization and faunal crisis, and then a return to the former trend. This event of the Messinian salinity crisis can be seen vividly in the changes in relative abundance and appearance of species, as shown in Figures 3 and 4, by the anomalous insertion of a large population of Cyprideis in a general faunal gradation. 


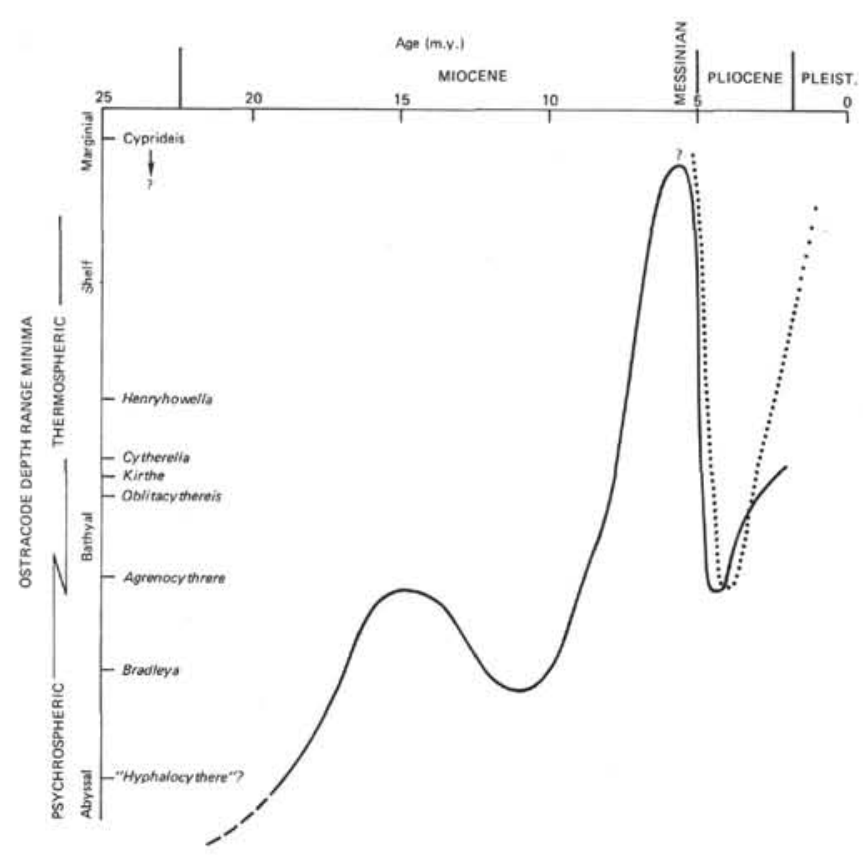

Figure 2. Changes in relative depth or temperature minima in the western basins (solid line) and eastern basins (dotted line) through time as indicated by the ostracodes.

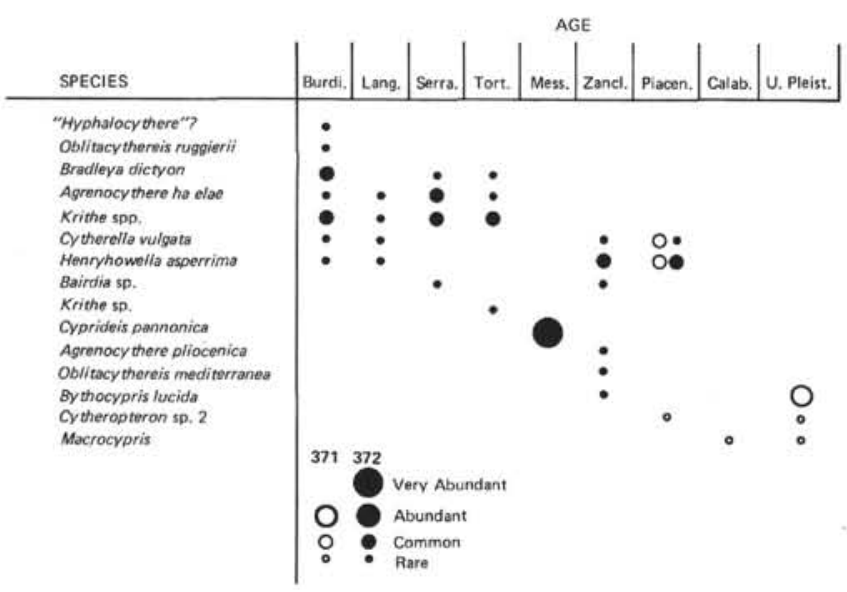

Figure 3. The relative abundance of ostracode species through time as found in the western basins of the Mediterranean.

The faunal changes through time are not the same in the eastern basins as in the west, except for the occurrence of the Cyprideis fauna. Elements of the Langhian fauna, described from the stratotype by Oertli (1961), were found in cores of this age at Site 375 (Table 3 ). This is a poorly known restricted basin fauna. The Serravallian and Tortonian is azoic, so far as ostracodes are concerned, in the eastern basins. In sediments deposited after the caspibrackish Cyprideis fauna was eliminated by the invasion of marine waters (Agrenocythere pliocenica was identified in the Zanclian of Site 378 , Sample 11-4, $110-112 \mathrm{~cm}$, although there is doubt about this determination), sparse deep thermospheric faunas occur intermixed with sapropelic zones and obvious evidence of times of low

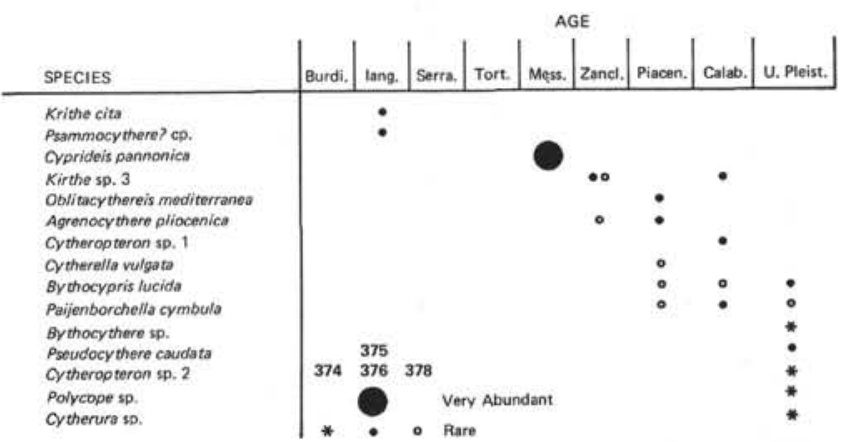

Figure 4. The relative abundance of ostracode species through time as found in the eastern basins of the Mediterranean.

benthic productivity. Oblitacythereis mediterranea (Plate 1, Figure 5), also characteristic of the Myrtou Formation (Zanclian) of Cyprus, is characteristic of the earlier history of the eastern basins, as is Paijenborchella cymbula (Plate 1, Figure 1). This latter genus is found in deep thermospheric Tethyan basins from Indonesia westward. The Pleistocene faunas of the eastern and western basins are similar; Cytheropteron (Plate 2, Figure 2) is a common form.

The post-Messinian ostracode fauna of the Aegean Sea (Site 378) was rather poor, and is mentioned here rather than tabulated. Seven samples of Pleistocene to Zanclian age yielded only 29 specimens of six species, including Paijenborchella cymbula (Piacenzian and Pleistocene) and Agrenocythere pliocenica (Zanclian). No ostracodes were found in the section with sapropels (Core 8, Section 2). This fauna is essentially the same as that of the upper section of Site 376.

There is one anomaly in the faunal trends as shown in Figure 2: the downward dip of depth minima indicated between 10 and 15 m.y.B.P. This may be an artifact of sampling, but it is shown because it is uncertain if the reappearance of Bradleya at Site 372 in the Serravallian or earliest Tortonian is an authentic record or contamination. If it is contamination, the decay of the psychrosphere was more gradual, as I predicted earlier (Benson, 1973a). If it is a true occurrence, then it is possible that there could have been an important fluctuation that might otherwise have been overlooked.

\section{THE OSTRACODES AND LEG 42A OBJECTIVES}

The shipboard report listed several objectives for drilling at each site. The following comments are to address some of these objectives, on the basis of the results of the ostracode evidence.

Site 371, Knoll above the Balearic Abyssal Plain: The ostracode evidence here is not in disagreement with the hypothesis of a Pliocene depth of 1500 to 2000 meters, but is indirect from Site 372.

Site 372, Algero-Provencal Basin (Balearic Basin?): The ostracodes indicate that the age of these basins exceeds that of the oldest sediments penetrated by drilling, and suggest oceanic origins, at least from the biologic point of view. The eastward influence of 
Paratethys during the Messinian salinity crisis is indicated by the abundant presence of Cyprideis. The influence of the Atlantic Ocean during the middle Miocene is readily demonstrated by the presence of the typical Atlantic deep-sea ostracode Bradleya dictyon. The influence of the Indian Ocean at depth is ambiguous because (1) it was predominantly thermospheric through Tethys, and (2) evidence is lacking to the east. The depths indicated by the ostracodes agree well with those of the benthic foraminifers (fide, R. Wright).

Site 373A, Tyrrhenian Basin: The ostracodes offer no important additional information.

Site 374, Ionian Basin: The ostracode evidence was very poor and disappointing. The samples were barren within the sapropelic sequences and above, except in one Pleistocene sample. This negative evidence suggests poor circulation in the Ionian Basin, and that azoic conditions formed a biologic barrier at depth toward the south and east. If the identification of an upper psychrospheric ostracode in the Aegean Sea is correct, perhaps the barrier was not complete. A sill separating the eastern and western basins after the Messinian is suggested by the ostracode evidence. This hypothesis does not explain why much of the early Pliocene evidence of good and deep circulation now occurs in outcrop on the south and east coasts of Italy facing the present Ionian Basin.

Sites 375 and 376, Florence Rise, west of Cyprus: The ostracode evidence was especially plentiful in the Messinian lac mer sequence, and indicates, from an in situ assemblage, that Paratethyan influences dominated the deep eastern basins with shallow Caspian-like lakeseas. Some local slumping is indicated (Oblitacythereis mediterranea occurred a little high in the section; Site 376 , Sample $5-5,70-80 \mathrm{~cm}$ ), but nothing suggests that Cyprideis is allochthonous. The absence of ostracodes supports the view that the middle Miocene sediments were deposited in a stagnant basin; but the deep Langhian fauna indicates that some beneficial circulation existed before this time.

Site 377: Not studied.

Site 378, Aegean Basin: Sapropels occur in the Pliocene part of this section, along with a single specimen of Agrenocythere pliocenica, an upper psychrospheric ostracode. If contamination or misidentification could be demonstrated, this would clarify matters here considerably. The hypothesis that oceanic circulation touched this far east, even temporarily, as a consequence of the sudden Pliocene flooding, is not easy to accept. This mystery and the relationship of Paijenborchella to its Indonesian namesake will remain unsolved for a while.

\section{SUMMARY}

The ostracodes found in the cores collected on Leg $42 \mathrm{~A}$ were sufficiently plentiful and distinctive to show the following:

1) The basins of the Mediterranean and their waters have been deep for as long as a faunal record was present, except perhaps during the Messinian, when shallow(?) lac mer conditions were almost universal.
2) The western Mediterranean basins, or at least the southern Algero-Provencal and South Balearic basins, were not only deep during the middle Miocene, but were also connected to the Atlantic by a threshold that would allow species typical of the lower slope to enter.

3) After deterioration of Tethyan oceanic conditions, climaxed by the salinity crisis of the late Miocene, the waters of the western and eastern Mediterranean basins were suddenly invaded by species characteristic of the upper psychrosphere; that is, species that lived beneath the oceanic-sea benthic biologic barrier. Now at least one of these species has been found as far east as the Aegean Sea, in the lowermost Pliocene. This suggests that the Pliocene flood was much more significant, biologically or oceanographically, than is the present or was the Pleistocene Mediterranean condition.

4) The Neogene history of the Mediterranean basins, as it affected the ostracodes, is one of threshold control of water mass systems, suggesting two extremes: the first, open access to oceanic influence; the second, complete or almost complete closure of this access, thus allowing continental dominance. If the salts that form the evaporites came from the same source, the waters that carried them were not marine.

\section{ADDENDUM}

The designation of the pre-Messinian strata of Site 372 as Tortonian in this report may be questioned on the basis of foraminifer data (see Cita et al., this volume). The author received this information after submitting the manuscript. The ostracode species do not now give precise information about the Serravallian or Tortonian age; it is the belief of the author, however, that such a psychrospheric assemblage would have probably disappeared before the Tortonian was very old. It certainly does not dispute the interpretation of these strata as Serravallian. The reader should interpret the tables and charts with this possible age modification in mind.

\section{REFERENCES}

Benson, R. H., 1972. The Bradleya problem, etc: Smithsonian Contrib. Paleobiol., v. 12, p. 1-138.

1973a. An ostracodal view of the Messinian salinity crisis. In: Drooger, C. W. (Ed.), Messinian events in the Mediterranean: Amsterdam (North-Holland Publishing Company), p. 235-242.

1973b. Psychrospheric and continental ostracoda from ancient sediments in the floor of the Mediterranean. In: Ryan, W. B. F., Hsü, K. J., et al., Initial Reports of the Deep Sea Drilling Project, Volume 13: Washington (U.S. Government Printing Office), p. 1002-1008.

1975a. Morphologic stability in ostracoda: Am. Paleontol. Bull., v. 65 ; p. 13-46.

$1975 \mathrm{~b}$. The origin of the psychrosphere as re-

corded in changes of deep-sea ostracode assemblages: Lethaia, v. 8, p. 69-83.

in press. Miocene deep-sea ostracodes of the Iberian Portal and the Balearic Basin: Marine Micropaleontol. 
Benson, R. H. and MacDonald, H. C., 1963. Postglacial (Holocene) ostracodes from Lake Erie: University of Kansas Paleontological Contributions, Arthropoda, v. 4, p. 1-26.

Caspers, H., 1957. Black Sea and Sea of Azov: Geol. Soc. Am. Mem. 67, v. 1, p. 801-890.

Cita, M. B., 1973. Mediterranean evaporite: paleontological arguments for a deep-basin desiccation model. In Drooger, C. W. (Ed.), Messinian events in the Mediterranean; Amsterdam (North-Holland Publishing Co.), p. 206-228.

Elofson, O., 1941. Zur Kenntnis der Marinen Ostracoden Swedens: Zoologiska Bichag fran Uppsala, v. 19, p. 215534.

Decima, A., 1964. Ostracodi del genere Cyprideis Jones del Neogene e del Quaternario italiani: Paleontol. Ital., v. 57, p. 81-133.

Krstić, N., 1968. Ostracodes des couches congeriennes: 3. Cyprideis II: Mus. Hist. Natur. Bull., Ser. A, v. 23, p. 153183.
1971. Ostracode biofacies in the Pannone. In Oertli, H. J. (Ed.), Paleoecologie ostracodes: Centre Recherches Pau-SNPA Bull., v. 5; p. 391-397.

Oertli, H. J., 1961. Ostracodes du Langhien-Type: Riv. Ital. Paleontol., v. 67, p. 17-44.

Peypouquet, J.-P., 1975. Les variations des caracteres morphologiques internes chez les Ostracodes des genres Krithe et Parakrithe relation possible avec la tenure en $\mathrm{O}_{2}$ dissous dans l'eau: Institut de Geologie du Bassin d'Aquitaine Bull., v. 17; p. 81-88.

Pokorny, V., 1952. The ostracodes of the so-called Basal Horizon of the Subglobosa Beds at Hodonin (Pliocene, Inner Alpine Basin Czechoslovakia): Sbornik Ustredniho Ustavu Geologickeho, v. 19, p. 1-168.

Ryan, W. B. F., Hsü, K. J., et al., 1973. Initial Reports of the Deep Sea Drilling Project, Volume 13: Washington (U.S. Government Printing Office).

Sokač, A., 1972. Pannonian and Pontian ostracode fauna of Mt: Medvednica: Paleontol. Yugoslavia, v. 11, p. 1-140. 


\section{PLATE 1}

Figure $1 \quad$ Paijenborchella sp.

USNM 191705; Sample 378-3, CC. $\times 180$. Piacensian.

Figure 2 Bythocythere sp. USNM 191706; Sample 374-1-2, 100-106 cm. $\times 250$. Pleistocene-N22.

Figure $3 \quad$ Henryhowella asperrima Reuss. USNM 191707; Sample 372-3-3, 103-109 cm. $\times 115$. Zanclian.

Figure $4 \quad$ Bradleya dictyon (Brady). USNM 191708; Sample 372-14-2, $90-97 \mathrm{~cm}$. $\times 120$. Lower Tortonian.

Figure $5 \quad$ Oblitacythereis mediterranea Benson.

Male; USNM 191250; Sample 376-5-5, 70-80 $\mathrm{cm} . \times 110$. Piacenzian? (Zanclian).

Figure $6 \quad$ Oblitacythereis mediterranea Benson.

Female; USNM 191709; Sample 372-3-3, 103$109 \mathrm{~cm} . \times 100$. Zanclian.

Figures 7, 8 Agrenocythere hazelae (Van den Bold).

USNM 191710; Sample 372-15-3, 24-30 cm. $\times 70,195$. Middle Miocene - N13? (Serravallian). 
PLATE 1
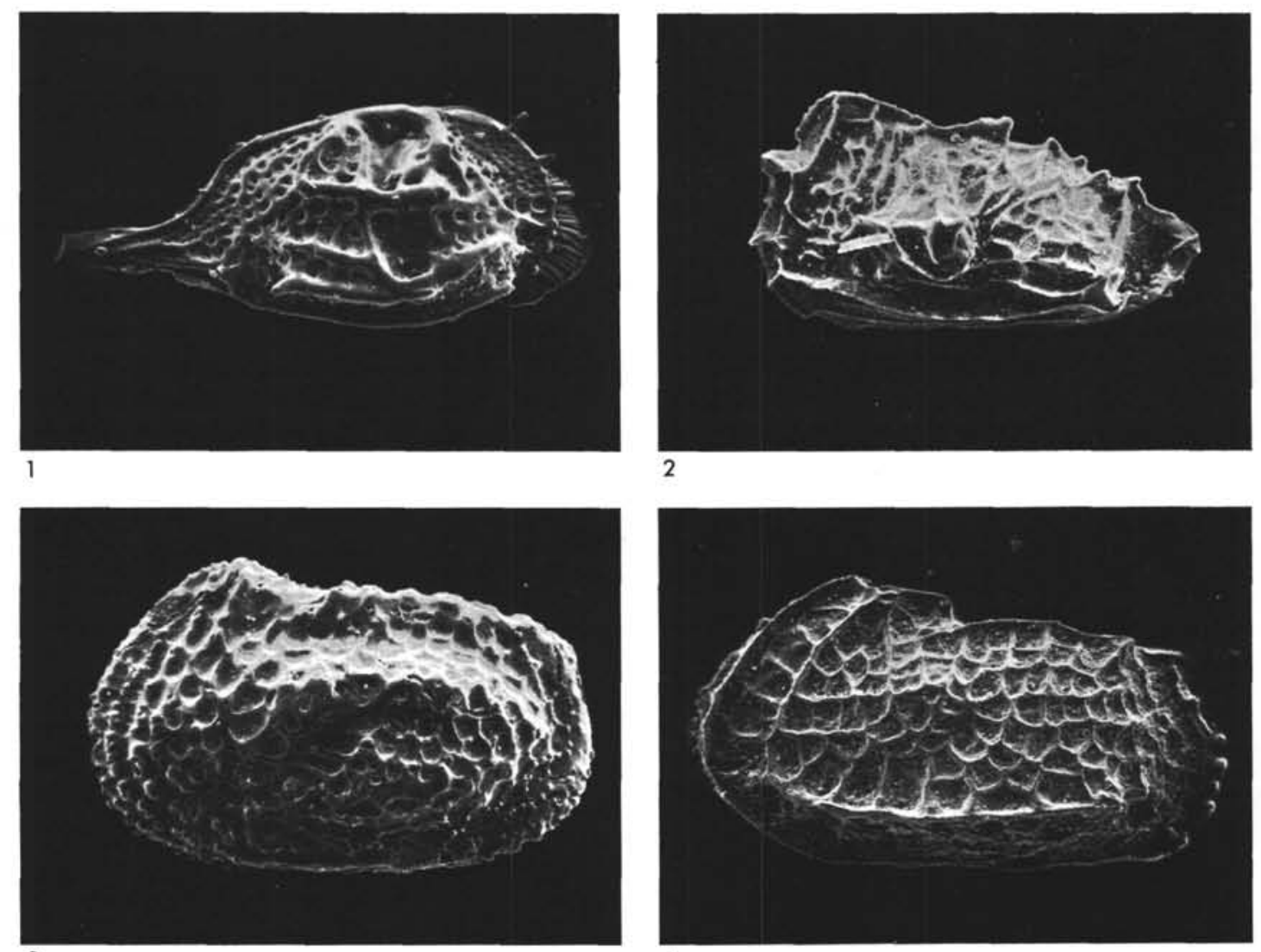

2

3
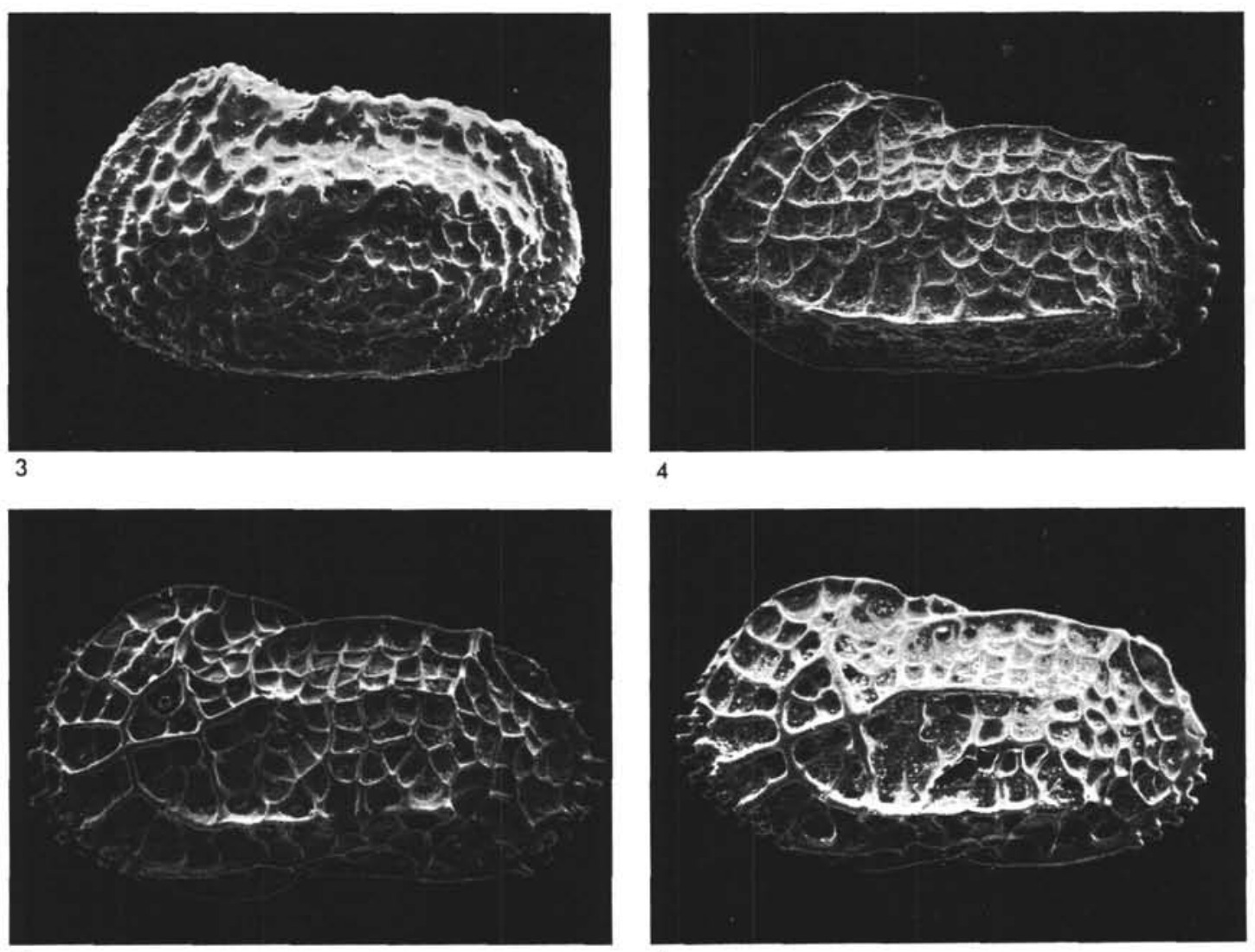

5

6
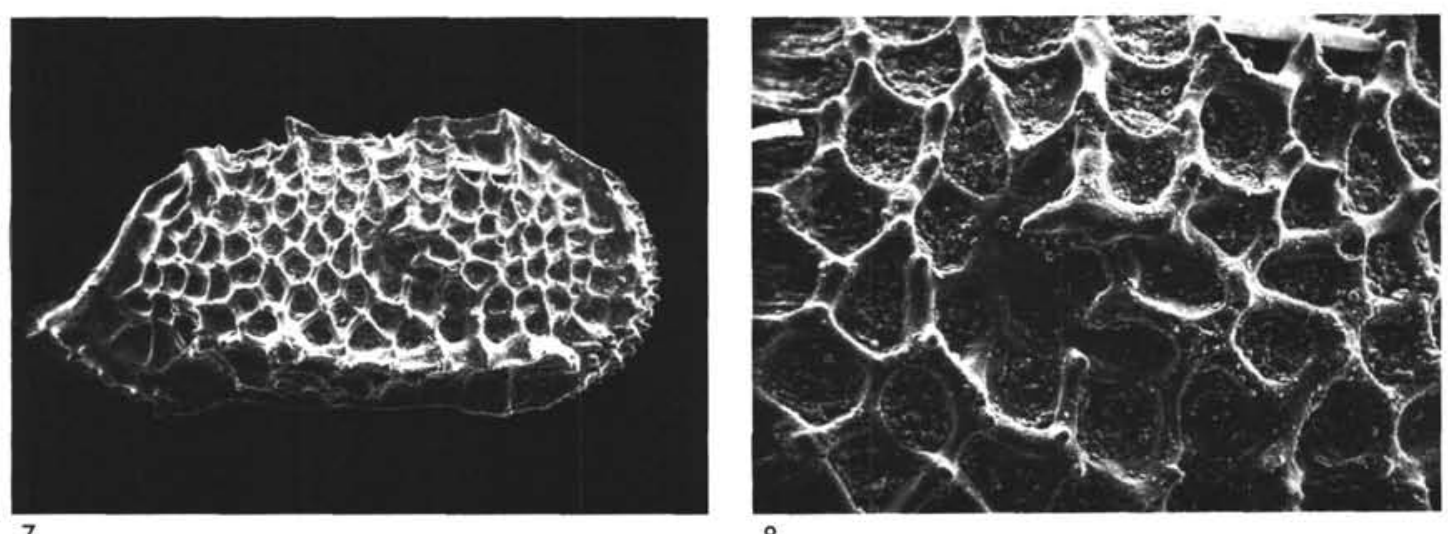

8 
PLATE 2

Figure $1 \quad$ "Hyphalocythere"?.

USNM 191711; Sample 372-33-3, 53-59 cm. $\times 110$. Burdigalian.

Figure $2 \quad$ Cytheropteron sp. 2.

USNM 191712; Sample 371-4-4, 70-76 cm. $\times 180$. Piacensian.

Figure 3 Cytherella vulgata.

USNM 191712; Sample 372-2-3, 90-96 cm. $\times 100$. Piacensian.

Figure $4 \quad$ Cyprideis pannonica Mehes.

Male; USNM 191714; Sample 376-9-3, 88-94 $\mathrm{cm} . \times 100$. Messinian.

Figure 5 Cyprideis pannonica Mehes.

Female interior; USNM 191715; Sample 3769-3, 88-94 cm. $\times 100$. Messinian.

Figure 6 Cyprideis pannonica Mehes.

Male interior; USNM 191716; Sample 376-9-2, $120-122 \mathrm{~cm} . \times 100$. Messinian.

Figure 7 Cyprideis pannonica Mehes.

Female; USNM 191716; Sample 376-9-2, 120 $122 \mathrm{~cm} . \times 100$. Messinian.

Figure $8 \quad$ Cyprideis pannonica Mehes.

Muscle scars; USNM 191715; Sample 376-9-3, $88-94 \mathrm{~cm} . \times 370$. Messinian. 


\section{PLATE 2}
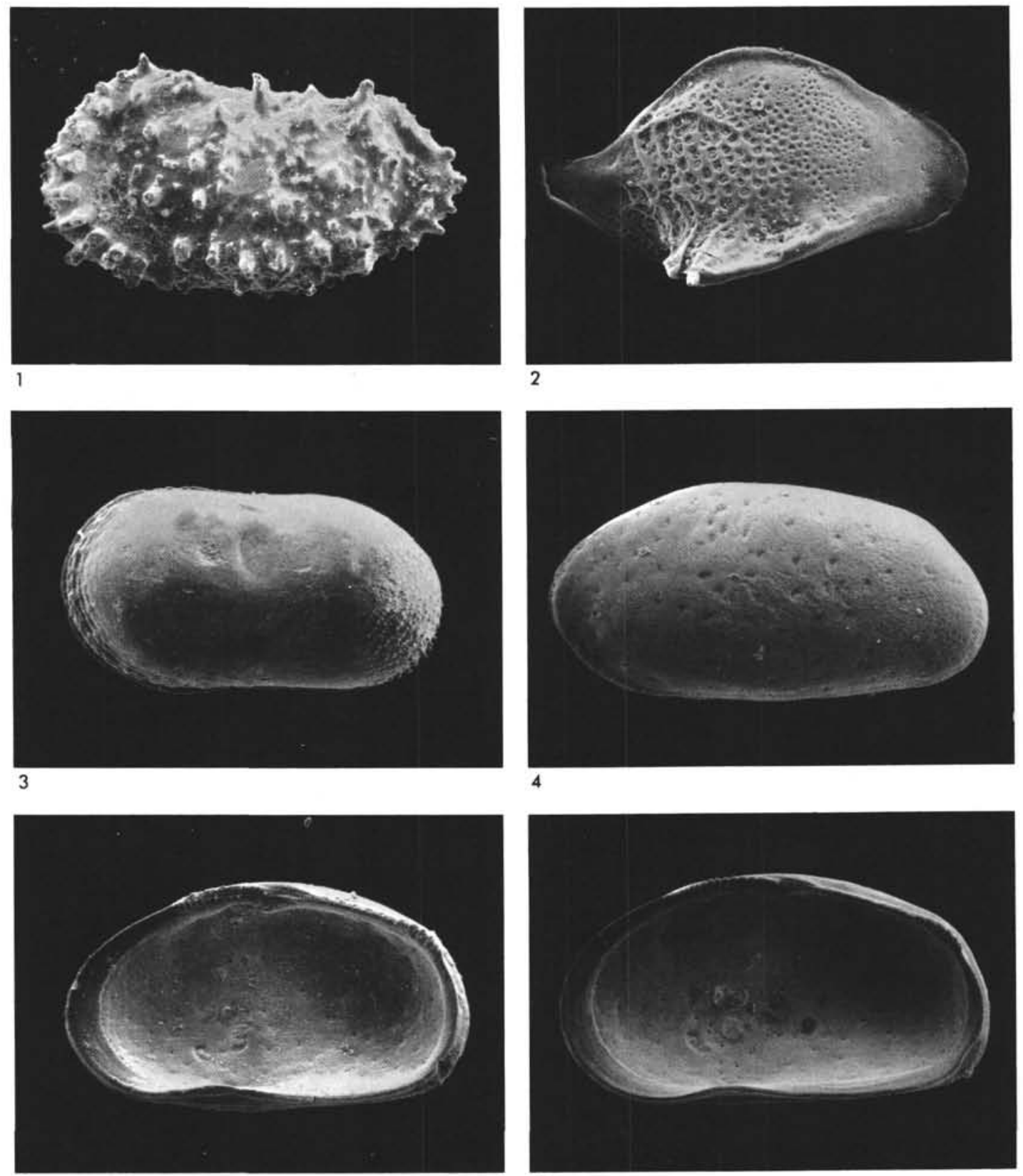

5
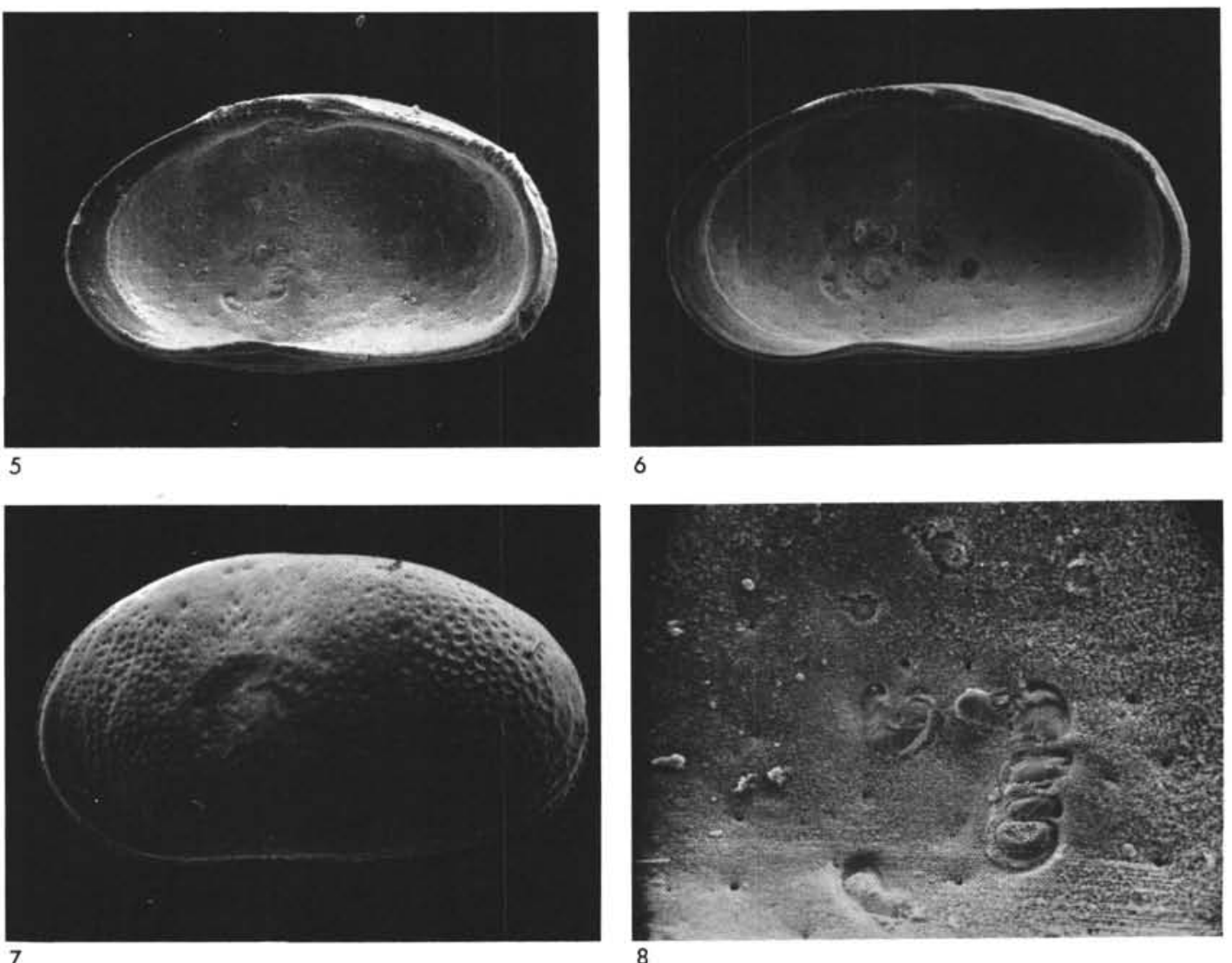